\author{
Department of Anatomy (Prof. T. Iтo), Hokkaido University School of Medicine, \\ Sapporo, Japan
}

\title{
Tubular Complex of Small Lymphocytes in Lymphatic Tissues of the Mouse
}

\author{
Kazuhiro AвE and Takashi ITo
}

Received June 27, 1974

\begin{abstract}
Summary. Electron microscopy of small lymphocytes in the lymphatic tissues of mice revealed that they contained a peculiar tubular complex in the cytoplasm. The complex consisted of an accumulation of tortuous tubules measuring 400 to $500 \AA$ in diameter, coated vesicles and multivesicular bodies. Its occurrence was most frequent in small lymphocy tes in the peripheral lymphatic tissues, although varying in different lymphatic tissues. After an intravenous injection of ferritin, some of the complexes were labeled by ferritin. The complex is considered as an intrinsic cytoplasmic element in lymphocytes and seems likely to develop in relation to the functional maturation of lymphocytes.
\end{abstract}

Lymphocytes are known to play an important role in immunity, although their exact role in immune responses has not yet been fully understood. The morphology of lymphocytes has recently been documented in detail in the literature at the ultrastructural level as well as at the light microscopic level (Hunn and Stich, 1969; MoRI and LenNert, 1969; Yoffey and Courtice, 1970; TANaka and Goodman, 1972; Bessis, 1973). The recent development of electron microscopy has enabled us to reveal the fine structure of lymphocytes, but little information is available about the specialized structures associated with the functional activity of lymphocytes. Even at present lymphocytes are generally considered to be unspecialized in appearance. In certain lymphatic tissues of mice of various ages in both normal and immunologically activated conditions, we have observed by electron microscopy that small lymphocytes often contain unique cytoplasmic structures, termed as tubular compexes, which appear to develop during the functional maturation of small lymphocytes particular$1 \mathrm{y}$ in the thymus and its dependent area of peripheral lymphatic tissues (ABE, 1968; AвE and Iто, 1970; Аве, Sasaki and Iто, 1973) In this study we undertook systematically to examine the occurrence of the cytoplasmic structures in small lymphocytes in lymphatic tissues of mice at various ages.

\section{Material and Methods}

Since 1965 lymphatic tissues from more than 300 dd-mice of both sexes ranging in age from birth to 180 days have been observed by electron microscopy in this laboratory. The tissues including thymus, spleen, lymph nodes, Peyer's patches and bone marrow from the femur were generally prefixed in $5 \%$ formol in $0.05 \mathrm{M}$ phosphate buffer ( $\mathrm{pH} 7.5$ ) containing $1.5 \%$ sucrose for 24 to $48 \mathrm{hrs}$ at $4^{\circ} \mathrm{C}$ and postfixed in $2 \% \mathrm{OsO}_{4}$ in the same buffer for 1.5 to $2 \mathrm{hrs}$. The tissues were embedded in Epon and sectioned with glass knives on an LKB ultratome. Ultrathin sections stained with uranyl acetate and lead citrate were examined in Hitachi electron microscopes (HS-7D, HS-8). In addition, 39 mice, two months old, were injected intravenously 
with $50 \mathrm{mg}$ of cadmium-free horse ferritin (Nutritional Biochemical Co., Cleveland, Ohio) which had been purified in the same way as referred to in a previous paper ( $\mathrm{ABE}$ and ITo, 1974). Then the lymphatic tissues were removed at various time intervals ( $30 \mathrm{sec}$ to $24 \mathrm{hrs}$ ) after injection. In the ferritin experiment, the unstained or stained ultrathin sections were observed by electron microscopy. Another 9 mice received a second injection of ferritin 2 weeks after the primary injection, and their lymphatic tissues were examined by electron microscopy in the same way as above. In addition to lymphocytes in mice, lymphocytes in several human tissues obtained by biopsy were also examined by electron microscopy.

\section{Observations}

Tubular complexes were frequently encountered in the cytoplasm of small lymphocytes in the lymphatic tissues thus examined. The tubular complexes consisted of a mass packed with tubules, and they were often associated with coated vesicles and multivesicular bodies (Fig. 1). The tubules, 400 to $500 \AA$ in diameter, were smooth in contour and variable in length. They were sometimes as long as $1 \mu$. The tubules usually ran in an irregularly tortuous course and were often branching and anastomosing. In a single complex, tubules were also variable in number, being from several to as many as 50 . Occasional tubules exhibited a slight expansion at one end. Coated vesicles, approximately $500 \AA$ in diameter, were often attached to the tubules. They were also seen free near and occasionally between the packed tubules. A few multivesicular bodies were also associated with the complexes. The multivesicular bodies, bounded with a limiting membrane, were about $0.5 \mu$ in diameter and contained varying numbers of small vesicles. The bodies were often irregular in shape, sometimes showing a horseshoe-shaped profile on sections. Small vesicles were sometimes in contact with the limiting membrane. They were occasionally arranged like a crown or rosette just outside the bodies.

The tubular complexes were often located near the Golgi apparatus, with which however they were not associated directly (Fig. 2, 3). A single complex was usually contained in a single lymphocyte. Occasionally, however, there were two or more complexes in a lymphocyte. The tubules of the complex were rarely associated directly with the cell membrane.

Occurrence of the tubular complexes in small lymphocytes appeared variable in frequency in different lymphatic tissues. In the thymus, the complexes were rarer and less developed in cortical lymphocytes than in medullary lymphocytes. In the bone marrow, they were poorly developd, but they were generally more frequent than

Fig. 1. Details of tubular complexes. a. Two tubular complexes are seen in the cytoplasm of a small lymphocyte in the lymph node. $\times 20,000$ b. A tubular complex associated with multivesicular bodies in a small lymphocyte in a lymph node. $\times 27,000$ c. Tubular complex is poorly developed in a thymic small lymphocyte. $\times 27,000$ d. An accumulation of tortuous tubules in a small lymphocyte in Peyer's patch. $\times 30,000$ e. A long tubule in the complex in a small lymphocyte in Peyer's patch. $\times 30,000$ f. Tubules branching and anastomosing in a samll lymphocyte in the splenic lymphatic tissue. $\times 27,000$ g. Several coated vesicles around the complex in a small lymphocyte in the splenic lymphatic tissue. $\times 27,000$ h. A horseshoe-shaped multivesicular body in the complex in a small lymphocyte in Peyer's patch. $\times 30,000$ i. A multivesicular body surrounded by small vesicles. $\times 27,000$ j. A well developed complex in the cytoplasm of a large lymphocyte in the splenic lymphatic tissue. $\times 23,000$ 

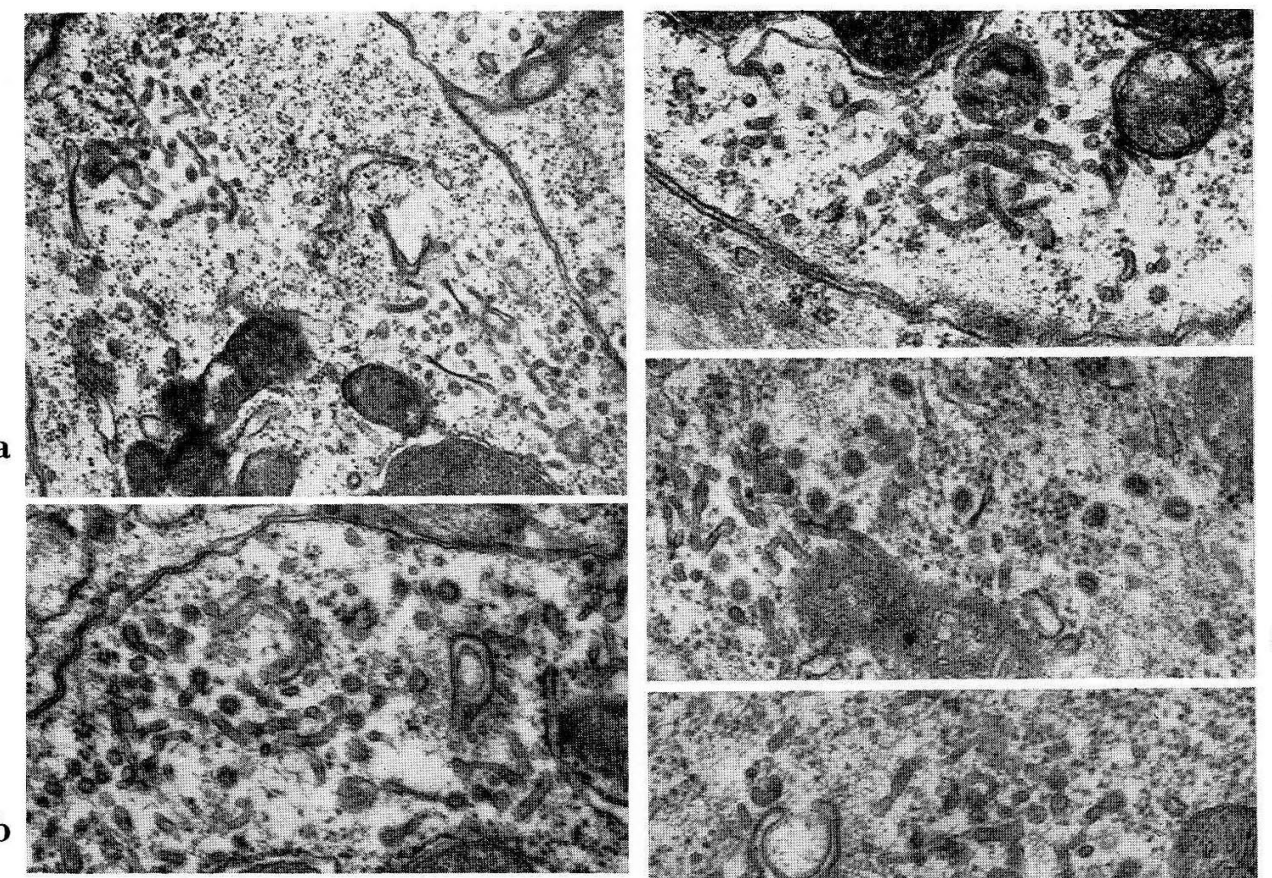

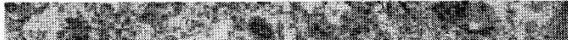

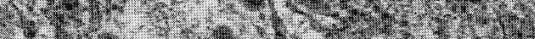

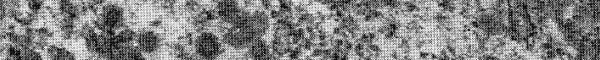

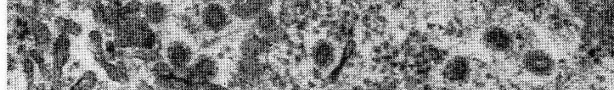

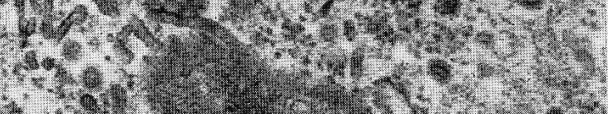

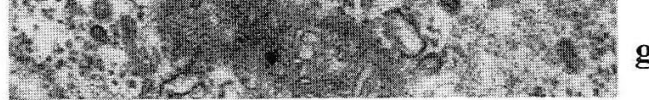

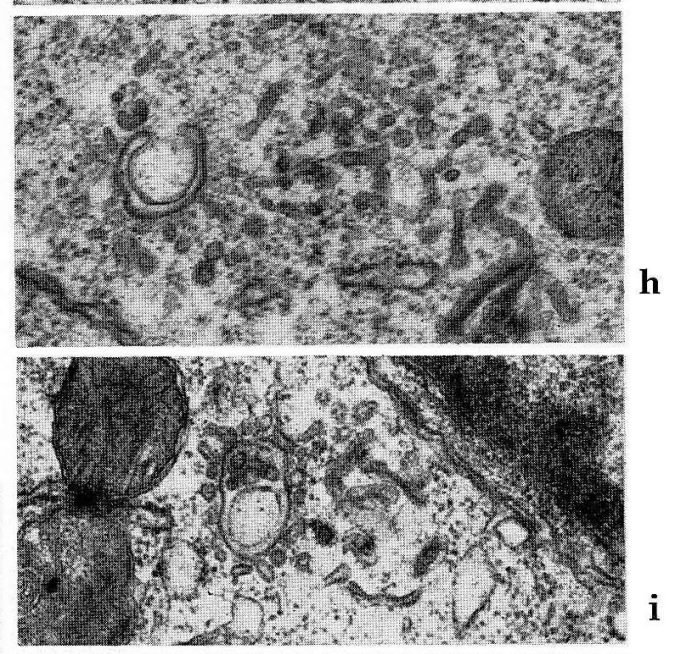

d

28,

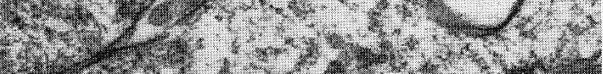

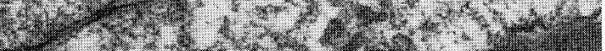

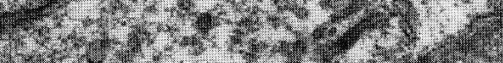

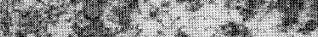

c

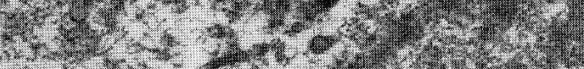

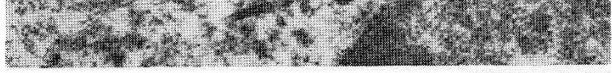
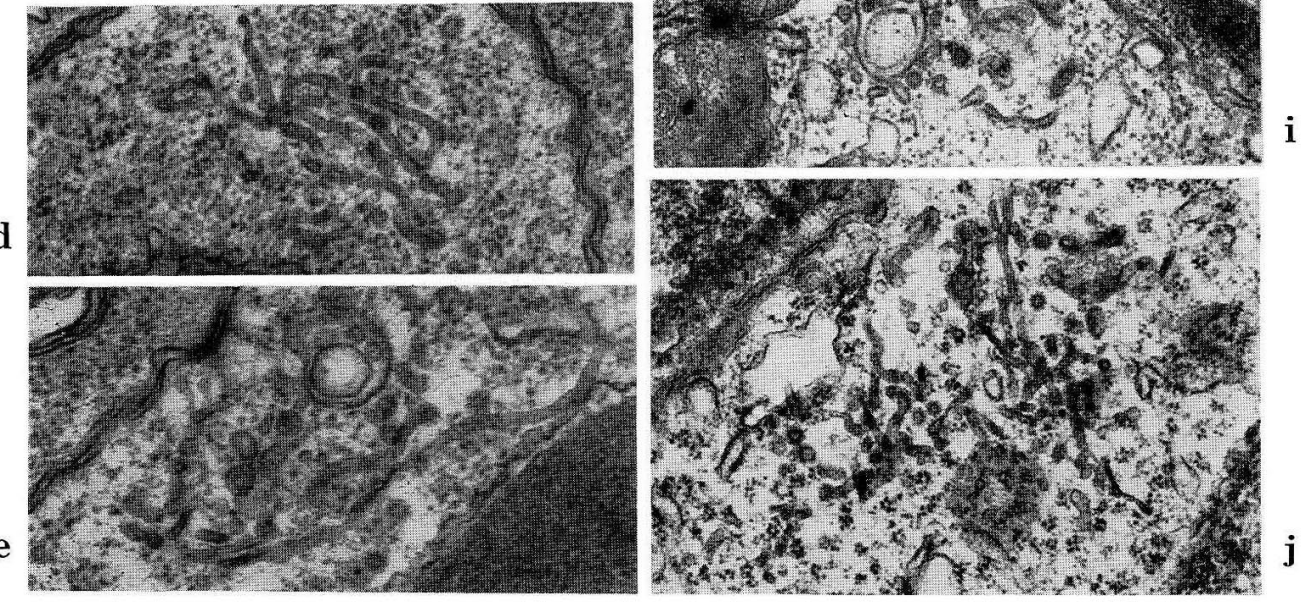

Fig. 1. 



b
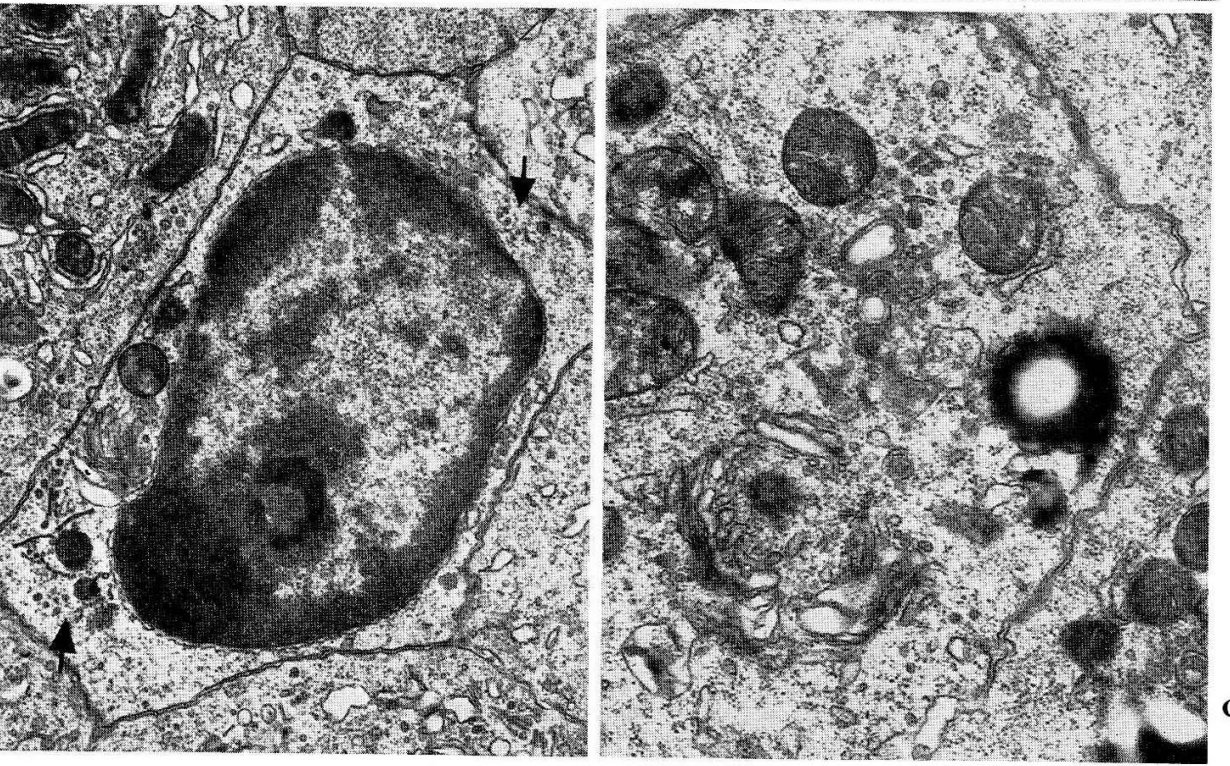

Fig. 2. a. A small lymphocyte in the lymph node. It contains tubular complexes (arrows) near and distant from the Golgi apparatus. $\times 15,000 \quad$ b. A small lymphocyte between endothelial cells of a postcapillary venule in the lymph node. Two tubular complexes (arrows) are seen: one near the Golgi apparatus and the other distant from the Golgi apparatus. $\times 10,000$ c. Cytoplasm of a small lymphocyte in the splenic lymphatic tissue. A tubular complex is located near the Golgi apparatus, but it shows no direct association with the Golgi apparatus. $\times 17,000$ 


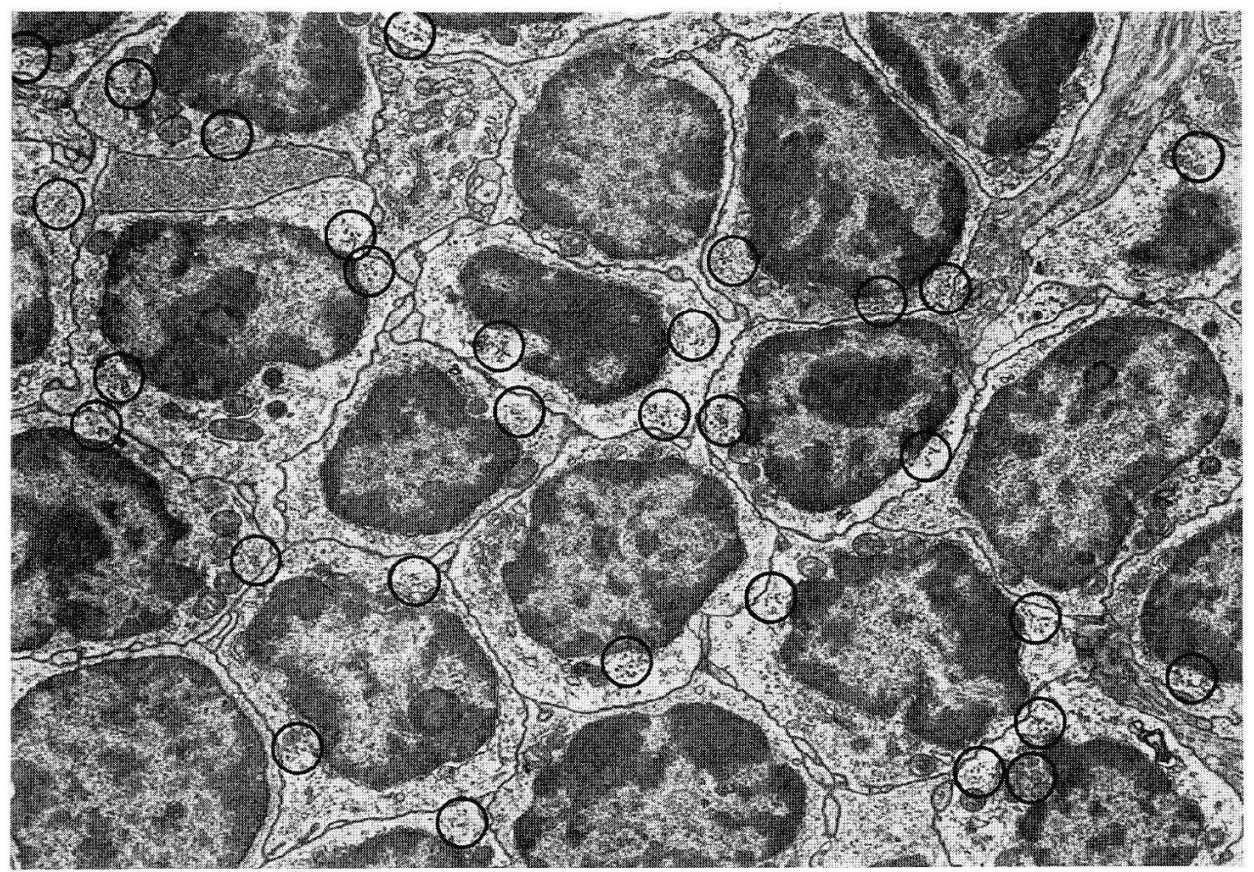

Fig. 3. Periarterial area in the splenic lymphatic tissue. Small lymphocytes have tubular complexes which are seen in the encircled areas. $\times 5,000$

those in thymic cortical small lymphocytes. In small lymphocytes of the splenic lymphatic tissue, lymph nodes and Peyer's patches, the complexes were usually more numerous and better developed. In the splenic lymphatic tissue, the tubular complexes occurred most frequently in the periarterial area, where more than $80 \%$ of small lymphocytes contained the complexes (Fig. 3). The actual incidence seems higher, because the complexes were encountered when the cells were sectioned on an appropriate plane.

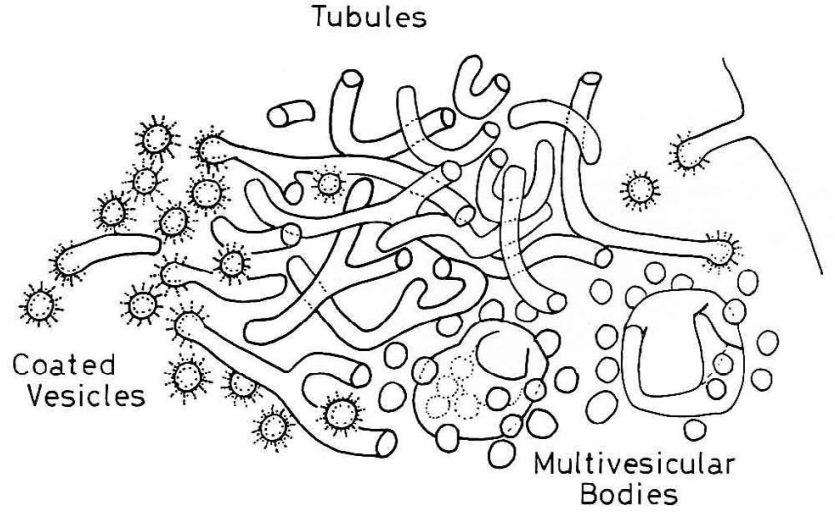

Fig. 4. Schematic diagram of a tubular complex. The complex consists of an accumulation of tubules, coated vesicles and multivesicular bodies. 
The tubular complexes occasionally appeared in immature large or medium lymphocytes (Fig. $1 \mathrm{j}$ ), but they were not detected in any other cells than lymphocytes in the lymphatic tissues thus far examined.

The tubular complex is diagrammatically shown in Figure 4.

\section{Ferritin experiment}

The thymus and splenic lymphatic tissue were examined after an intravenous injection of ferritin. In the thymus, small amounts of ferritin particles were observed in the parenchyma, 15 minutes after the injection, but few lymphocytes were labeled with ferritin. In the spleen, large amounts of ferritin had leaked from the sinuses into its lymphatic tissue immediately after the injection, and some small lymphocytes were labeled by ferritin (Fig. 5). In the small lymphocytes labeled, ferritin was seen within the endocytotic vesicles just inside the plasma membrane soon after the injection. After 15 min and more, ferritin could be detected in some of the tubular complexes along the cell surface. Ferritin particles were more often contained within the multivesicular bodies. At 24 hrs after the injection, the tubular complexes containing ferritin were slightly increased in the periarterial lymphatic sheath. No recognizable differences were seen in the extent of ferritin labeling after the primary and secondary injections.

a
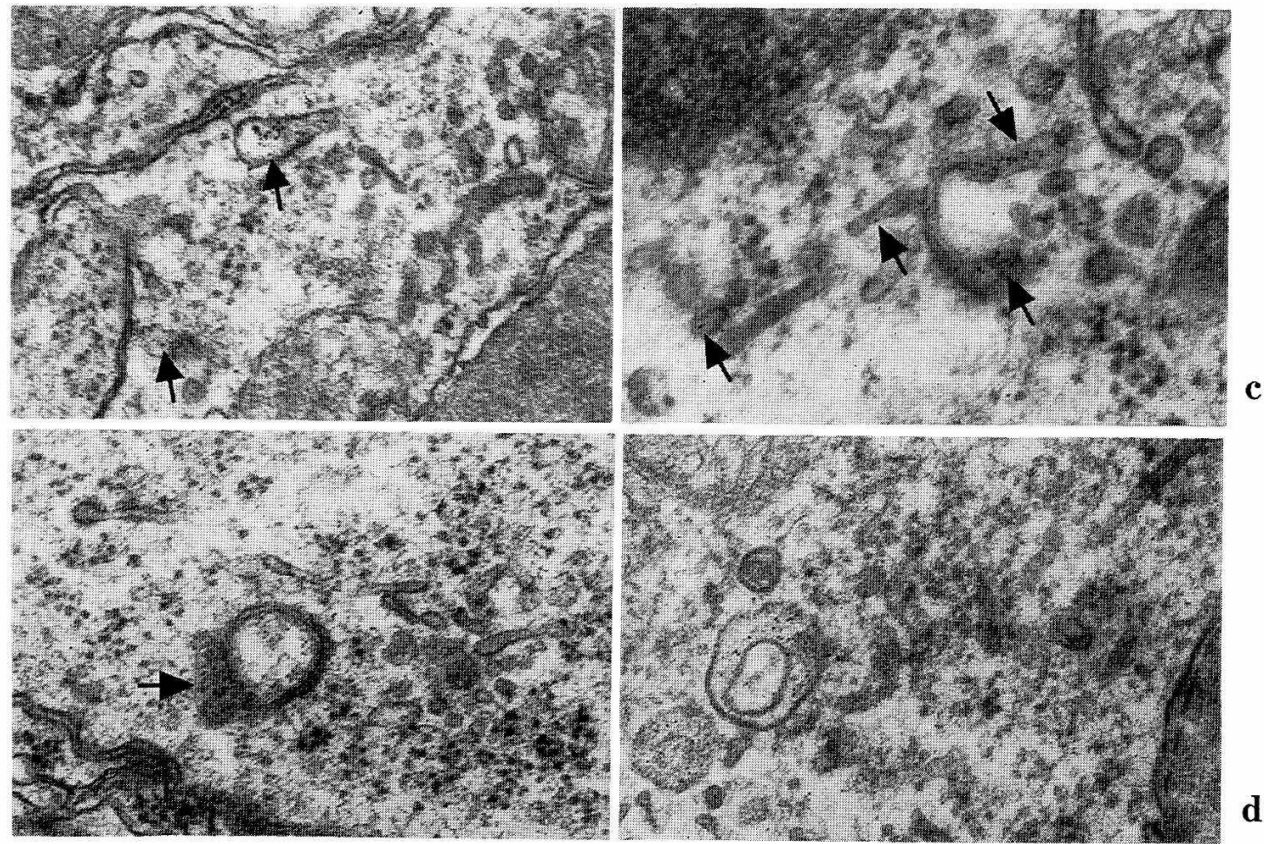

Fig. 5. Small lymphocytes in the splenic lymphatic tissue after intravenous injection of ferritin. a. 5 min after injection. The endocytotic vesicles just inside the plasma membrane contain ferritin (arrows). A tubular complex is seen near the vesicles. $\times 30,000 \quad$ b. 15 min after injection.

Ferritin particles are seen in a multivesicular body of the tubular complex (arrow). $\times 30,000$

c. 30 min after injection. The tubular complex is labeled by ferritin (arrows). $\times 57,000$

d. 60 min after injection. Multivesicular bodies and tubules are labeled. $\times 30,000$ 


\section{Discussion}

The tubular complex is considered as an intrinsic cytoplasmic feature in the lymphocytes of mice, although its occurrence and development appear to be different in lymphocytes from different lymphatic tissues. Similar structures, though termed differently by previous investigators, have been reported in human lymphocytes in certain experimental and pathological conditions such as autoimmune diseases or lymphoid tumors (Hovig, Jeremic and Stavem, 1968; Huhn, 1968; Györkey and Sinkovics, 1971; Kaiserling, 1972; White, 1972; Pothier, et al., 1973; SchafF, Barry and GRIMLEY, 1973). The tubular complex described in this paper, however, is not exactly a counterpart of similar structures in the literature, because the tubular structures observed by the previous investigators were considerably smaller in diameter than those in the tubular complex and they are generally located within the endoplasmic reticulum, showing reticular arrays. In addition, the previous investigators have observed that the tubular structures occurred in lymphoid cells under pathologic conditions. Cytoplasmic structures similar to the complex have been shown in lymphocytes in microphotographs of the publications available (MORI and Lennert, 1969; Sandborn, 1970; Matthews and Martin, 1971; Ebe and Kobayashi, 1972; TANAKA and GoODMAN, 1972), but they have not been particularly referred to by the previous authors. Similar structures to the tubular complex were also noticed in developing oocytes of various animals (WEAKLEy, 1966, 1968, 1973; Dyer, Ruby and SkALKo, 1973), although their functional significance was not discussed in particular. However, at least for the mouse the tubular complex occurs normally in considerably high incidence particularly in small lymphocytes.

Multivesicular bodies and coated vesicles are also related closely with the complex. It seems appropriate, however, to designate the complex as "tubular", because aggregated tubules are its consistent components. The tubules may possibly be endoplasmic reticulum in nature, which however is generally known to be rare in lymphocytes (TANAKa and Goodman, 1972). The tubular complex was also observed by us in lymphocytes in human tissues obtained by biopsy.

At present, it is generally accepted that small lymphocytes are heterogenous in origin and population, consisting of at least two populations, thymus-derived and bone marrow-derived (for reviews see Everett and Tyler, 1967; Miller and Osoba, 1967; Goldstein and Mackay, 1969; Yoffey and Courtice, 1970; Metcalf and Moore, 1971; ELVES, 1972). In the thymus, numerous small lymphocytes are produced through an active proliferation of large and medium lymphocytes in the cortex. Thymic small lymphocytes thus formed move from the cortex into the medulla, from which they are liberated to join a peripheral lymphocyte pool which recirculates through certain (thymus-dependent) areas of the peripheral lymphatic tissues. In the light of the recent concepts on the thymic function, lymphocytes are considered to be functionally "processed" to aquired immunological competence within the thymus. In previous papers we reported that in the thymus, cortical small lymphocytes are distinguishable in fine structure from medullary small lymphocytes and that small lymphocytes in the thymus-dependent area of the splenic lymphatic tissue are ultrastructurally similar to thymic medullary small lymphocytes (AвE and Iто, 1970; AвE, SASAKI and ITO, 1973). These findings suggest that morphological differences between 
thymic cortical and medullary small lymphocytes are associated with the functional maturation of small lymphocytes in the thymus and that medullary small lymphocytes migrate from the thymus and populate the thymus-dependent areas of peripheral lymphatic tissues. On the other hand, lymphocytes derived from the bone marrow are considered to form another population of lymphocytes in peripheral lymphatic tissues. Previously qualitative and quantitative analysis of fine structures of small lymphocytes in neonatal mice revealed that small lymphocytes in the bone marrow are ultrastruturally similar to thymic cortical small lymphocytes (ABE, SASAKI and Iто, 1973). It is now postulated that the marrow also provides the thymus with stem cells for thymic lymphocytes (for reviews see MILLER and OsobA, 1967; Yoffey and Courtice, 1970; Metcalf and Moore, 1971).

In a previous paper it was observed that in neonatal mice, the incidence of the tubular complex is different in small lymphocytes from myelolymphatic tissues including the thymus, splenic lymphatic tissue, bone marrow and liver: the frequency is greatest in the periarterial lymphatic sheath of the spleen, next in the thymic medulla, least in the thymic cortex and moderate in the myeloid tissue (ABE, SASAKI and Iто, 1973). In mice at all ages thus far examined, the tubular complex is generally better developed in small lymphocytes in the thymic medulla, splenic lymphatic tissue, lymph nodes and Peyer's patches than in the thymic cortex and bone marrow, as was the case in neonatal mice. Thus at least for small lymphocytes formed in and derived from the thymus, it is likely that the development of the tubular complex is related to lymphocyte maturation, because the complex appears to become more frequent with the maturation of small lymphocytes in the thymus and the thymusdependent areas of peripheral lymphatic tissues. For another population of lymphocytes, probably bone marrow-derived, however, it remains open whether or not a relationship exists between the development of the complex and the maturation of lymphocytes, because the exact population and behavior of this class of lymphocytes in peripheral lymphatic tissues are not yet fully understood.

It is generally inferred that thymus-derived lymphocytes are antigen-reactive and that antigens are recognized by contact onto the specific antibodies over the cell surface, although it is not certain how antigens actually interact with lymphocytes (Smith and LANDy, 1970; Nossal and AdA, 1971). It is not certain whether antigens enter the cytoplasm of lymphocytes or not, although uptake of ferritin by lymphocytes has been observed by earlier authors in lymphocytes in lymph nodes (HAN and JoHnson, 1966; HAN, HAN and Johnson, 1967) and in cultured lymphocytes added with ferritin in the medium (BIBERFELD, 1971). In cultured human peripheral blood lymphocytes transformed by phytohemagglutinin, BIBERFELD (1971) reported the presence of the "vacuolar system" which consists of small and large endocytotic vesicles, pale, dense and compound multivesicular bodies, vesicotubular structures and dense bodies, and observed that the vacuolar system is correlated to the endocytic activity of ferritin added to the culture medium. The present results indicate that ferritin which is thought to act also as an antigen, is taken up by small endocytotic vesicles and multivesicular bodies in small lymphocytes in the thymus and splenic lymphatic tissue and that small amounts of ferritin particles are sometimes contained also within tubules of the complexes. Thus our tubular complex is similar to the vacuolar system of BIBERFELD. 
To sum up, the complex appears to be one of the dynamic components in small lymphocytes, and it may provide some morphological clue for indicating the functional maturation and activity of small lymphocytes.

\title{
マウスのリンパ組織における小リンパ球の小管複合体
}

\author{
阿部和厚と伊藤隆
}

マウスのリンパ組織を電子顕徴鏡で観察すると, その胞体内にしばしば特異な小管複 合体が出現する．この構造は直径 400〜 $500 \AA$ の迁曲した小管の集積と被覆小胞，多 小胞体から成る：出現頻度は種々のリンパ組織によって異なるが，一般に末梢リンパ組 織のリンパ球にもっとも頻度が高い。フェリチンの静脈内注射を行なうと，一部の小管 複合体はフェリチンで標識される.

この複合体はリンパ球に特徵的な構造と考えられ，その発達は一般にリンパ球の機 能的成熟と関連すると考えられる.

\section{References}

Abe, K.: Light- and electron-microscopic studies of the thymus graft in the mouse (Japanese). Hokkaido J. med. Sci. 43: 208-241 (1968).

Abe, K. and T. Ito: Fine structure of small lymphocytes in the thymus of the mouse: qualitative and quantitative analysis by electron microscopy. Z. Zellforsch. 110: 321-335 (1970). 251-264 (1974).

Abe, K., K. Sasaki and T. Ito: Comparative ultrastructure and cytometric analysis of small lymphocytes in haemopoietic organs of neonatal mice. J. Anat. 115: 393-406 (1973).

Bessis, M.: Living blood cells and their ultrastructure. Heidelberg-New York, Springer-Verlag, 1973.

Biberfeld, P.: Endocytosis and lysosome formation in blood lymphocytes transformed by phytohemagglutinin. J. Ultrastr. Res. 37: 41-68 (1971).

Dyer, R. F., J. R. Rubby and R. G. Skalko: Ultrastructural observations on membranous structures in developing mouse oocytes. Z. Zellforsch. 137: 159-166 (1973).

Ebe, T. and S. Kobayashi: Fine structure of human cells and tissues. Tokyo, Igaku Shoin, 1972.

Elves, M. W.: The lymphocytes. 2nd ed. London, Lloyd-Luke, 1972.

Everett, N. B. and R. W. Tyler: Lymphocytosis in the thymus and other tissues: functional implications. Int. Rev. Cytol. 22: 205-237 (1967).

Goldstein, G. and I. R. Mackay: The human thymus. London, Heinemann, 1969.

Györkey, F. and J. G. Sinkovics: Microtubules of systemic lupus erythematosus. Lancet 1: 131-132 (1971).

Han, S. S., I. H. Han and A. G. Johnson: Quantitative studies of lymphocyte mobilization and uptake of antigen by lymphocytes during primary antibody response against protein antigens. In: (ed. by) H. Cottier, N. Odartchenko, R. Schindler and C. C. Congdon: Germinal center in immune responses. Berlin-Heidelberg-New York, Springer Verlag, 1967. (p. 199-207).

Han, S. S. and A. G. Johnson: Radioautographic and electron microscopic evidence of rapid uptake of antigen by lymphocytes. Science 153: 176-178 (1966).

Hovig, T., M. Jeremic and P. Stavem: A new type of inclusion bodies in lymphocytes. Scand. J. Haematol. 5: 81-96 (1968). 
Huhn, D.: Neue Organelle im peripheren Lymphozyten? Deut. med. Wochenschr. 94: 2099-2100 (1968).

Huhn, D. and W. Stich: Fine structure of blood and bone marrow. München, Lehmanns Verlag, 1969.

Kaiserling, E.: Verzweigte tubuläre Cytoplasmaeinschlüsse im menschlichen Lymphknoten. Beitr. Pathol. 147: 237-248 (1972).

Matthews, J. L. and J. H. Martin: Atlas of human histology and ultrastructure. Philadelphia, Lea and Febiger, 1971.

Metcalf, D. and M. A. S. Moore: Haemopoietic cells. Amsterdam-London, North-Holland Pub. Co., 1971.

Miller, J. F. A. P. and D. Osoba: Current concept of immunological function of the thymus. Physiol. Rev. 47: 437-520, (1960).

Mori, Y. and K. Lennert: Electron microscopic atlas of lymph node cytology and pathology. Berlin-Heidelberg-New York, Spinger-Verlag, 1969.

Nossal, G. J. V. and G. L. Ada: Antigens, lymphoid cells, and the immune response. New YorkLondon, Academic Press, 1971.

Pothier, L., B. G. Uzman, M. M. Kasac, H. Saito and R. A. Adams: Immunoglobulin synthesis and tubular arrays in the endoplasmic reticulum in transplanted human tumor of lymphoid origin. Lab. Invest. 29: 607-613 (1973).

Sandborn, E. B.: Cells and tissues by light and electron microscopy. Vol. 1. New York-London, Academic Press, 1970.

Schaff, Z., D. W. Barry and P. M. Grimley: Cytochemistry of tubuloreticular structures in 1ymphocytes from patients with systemic lupus erythematosus and in cultured human lymphoid cells. Lab. Invest. 29: 577-586 (1973).

Smith, R. T. and M. Landy (eds): Immune surveillance. New York-London, Academic Press (1970).

Tanaka, Y. and J. R. Goodman: Electron microscopy of human blood cells. New York-EvanstonSan Francisco-London, Harper and Row, 1972.

Weakley, B. S.: Electron microscopy of the oocyte and granulosa cells in the developing ovarian follicles of the golden hamster (Mesocricetus auratus). J. Anat. 100: 503-534 (1966). -: Comparison of cytoplasmic lamellae and membranous elements in the oocytes of five mammalian species. Z. Zellforsch. 85: 109-123 (1968).

-: Further observations on a cytoplasmic structure in the hamster oocyte. Z. Zellforsch. 146: 517-523 (1973).

White, J. G.: Giant organelles containing tubules in Chediak-Higashi lymphocytes. Amer. J. Pathol. 69: 225-238 (1972).

Yoffey, J. M. and F. C. Courtice: Lymphatics, lymph and the lymphomyeloid complex. LondonNew York, Academic Press, 1970.

\author{
阿部和厚 \\ =060 札幌市北15条西 7 丁目 \\ 北海道大学医学部 \\ 解剖学第三講座
}

Dr. Kazuhiro ABE

Department of Anatomy

Hokkaido University School of Medicine

Sapporo, 060 Japan 